$\mathrm{mm} . / \mathrm{V}$. input and paper speeds up to $200 \mathrm{~mm}$./sec. are available.

Hottinger Measuring Techniques, Ltd., Darmstadt, showed a range of miniature inductive pick-offs suitable for carrier frequencies of 5 and $50 \mathrm{kc} . / \mathrm{s}$., the minimum range being $20 \times 10^{-4} \mathrm{~mm}$. f.s.d., and a maximum operating temperature of $90-120^{\circ} \mathrm{C}$. according to type. Strain gauges with a minimum gauge-length of $3 \mathrm{~mm}$., and which would withstand a maximum strain of 2 per cent up to $200^{\circ} \mathrm{C}$., were also exhibited together with a strain gauge bridge torque-meter transmitting a maximum torque of 1,000 metre kiloponds, at 4,000 r.p.m. with a reproducibility of $\mathbf{0 . 5}$ per cent and on output of $1.5 \mathrm{mV} / \mathrm{V}$. supply at maximum torque loading; silver/silver graphite slip-rings with up to 12 channels, with brushes that may be replaced during running, were capable of running at 6,000 r.p.m. continuously and 12,000 r.p.m. intermittently.

Krohne of Duisburg displayed their range of rotameter-type flow-meters with magnetic pick-off of float position to provide remote indication, and a float-type density meter with inductive pick-off which fits directly into the process stream line and is independent of fluid velocity; the most sensitive range is $0.99-\mathrm{I} .01 \mathrm{gm}$./c.c. and the accuracy of this range is $\pm 1 \frac{1}{2}$ per cent. Heating or cooling coils and built-in temperature compensation are available. AB Lars Ljungberg, Sweden, demonstrated the 'Agnar' burette, a new and ingenious approach to precision metering, titrating and decanting. The burette has no tap, and is essentially a syringe in which the piston is positioned by means of a screw drive. Various syringe sizes are available, the $2 \mathrm{ml}$. size delivering $1 \mathrm{ml} . / \mathrm{rev}$. of the coarse $\mathrm{knob}$ and $12 \mu \mathrm{l}$./ rev. of the fine knob. The drive is reversible, thus the burette is equally suitable for drawing off any volume from $1 \mu l$. to $20 \mathrm{ml}$.

The Yokogawa Electric Works, Ltd., Tokyo, exhibited a range of direct-current precision measuring instruments including a good-looking miniature portable Wheatstone bridge. Panel meters were contemporary in style but appeared crudely manu. factured and designed without regard to their function of precise indication of a measured quantity. Fully transistorized printed-circuit strip-chart recorders of about 4-in. and 8-in. chart-width had self-folding charts facilitating reading of back records. A three-term electronic controller was on view but no information about it was available.

A new instrument under development by DISA Electronik measures departures from constancy of the angular velocity of rotating equipment at speeds up to 100,000 r.p.m.

\title{
ASSESSMENT OF PAIN IN MAN AND ANIMALS
}

A THREE-DAY symposium on the assessment of pain was organized by the Universitios Federation for Animal Welfare (UFAW) in collaboration with Prof. C. A. Keele, presided over by Sir Russell Brain, and held in the Department of Pharmacology at the Middlesex Hospital Medical School during July 26-28. UFAW had been asked to arrange such a symposium by Dr. C. Radouco-Thomas, secretary of the Collegium Internationale Neuro-PsychoPharmacologicum in Geneva, who made many useful suggestions. In his presidential address, Sir Russell Brain referred to the usefulness of bringing together the peripheral and central aspects of the nourology of pain and the need for reconsidering views which at present are widely held on the subject ; he said that UFAW's interest in the latter arose from the fact that pain sensations in many species appear to differ little from those experienced by man.

After Dr. K. D. Keele (London) had reviewed the history of theories of pain from primitive times, Prof. C. A. Keele (London) outlined a technique used by himself and his colleagues in which a blister is formed on the arm and the blister base is then stimulated in various ways, the resulting sensations being reported by the subject. The receptors appeared to be stratified in depth. The sensation at low levels of stimulation was not painful, and he proposed the term 'metæesthesia' for it under those conditions. Dr. Robert Smith (London) dealt with the quantita. tive relation between stimulus and sensation and described metæsthesia produced with potassium and polypeptide stimulations.

Prof. J. A. B. Gray (London) took the chair at a discussion of peripheral pain mechanisms. Dr. A. G. M. Weddell (Oxford) dealt with the structure of the nerve terminals in the skin as they appeared in elec. tron and optical microscopy. Prof. Y. Zotterman (Stockholm) dealt with the specificity of cutaneous nerve fibres and the search at sub-microscopical level for the cause of this specificity. Dr. A. Iggo (Edinburgh) discussed the conduction in single $C$ fibres of impulses initiated by noxious stimuli in the viscera, muscles and skin. Prof. H. Hensel (Marburg) showed a film record of afferent impulses in human single cutaneous nerve fibres. Dr. W. Koll (Göttingen) described the effects of morphine and other drugs on nociceptive spinal reflexes. An open discussion of the specificity of peripheral mechanisms followed.

Prof. D. Hill (London) presided over a session on central mechanisms of pain. Dr. D. R. Bowsher (Liverpool) and Prof. D. Albe-Fessard presented a joint paper showing that somatic sensations fall into two classes: discriminative sensations travelling by lemniscal pathways to the cortex via the thalamus and entailing a perception of location, and nondiscriminative sensations travelling by extra-lemniscal pathways. Dr. G. Gordon (Oxford) described the electrophysiological approach to central mechanisms of somatic sensation. Dr. P. W. Nathan (London) dealt with traces of pain remaining in the nervous system, as in the case of phantom limbs. Dr. J. Hankinson (Newcastle upon Tyne) described the relief of pain by destruction of intracerebral structures under the guidance of stereoscopic radiography. In the ensuing discussion, Prof. J. Scherrer (Paris) and Dr. G. L. Kidd (Liverpool) suggested possible mechanisms of phantom pain, and Dr. M. R. A. Chance (Birmingham) directed attention to audiogenic seizures which do not arise in rodents unless these are deprived of escape routes.

Prof. O. L. Zangwill (Cambridge) took the chair for a session on the assessment of pain in man. Dr. H. K. Beecher (Boston, U.S.A.) discussed some working hypotheses and described his work on the offect of drugs on high-level intellectual performance. 
He considered that data from experimental pain are often difficult to relate to clinical experience. Dr. J. D. Hardy (New Haven, Connecticut) described work on the pain threshold in relation to measurement of the intensity of human pain and the effects of analgesics. Dr. R. W. Houde (Now York) said that an analysis of quantitative data on pathological and experimental pain in terms of the 'ridit' unit could establish a relation between these two different types of data. Dr. C. Wilson (Liverpool) discussed the factors affecting the placebo response, which may give rise to bias even in blind experiments. A general discussion of psychophysical correlation problems followed.

In a session devoted to the assessment of pain in animals, with Prof. C. A. Keele (London) in the chair, Dr. D. D. Bonnycastle (Jersey City), Dr. R. L. Kitchell (Minnesota), Dr. H. O. J. Collier (London), Dr. C. Radouco-Thomas (Geneva), Dr. K. Soehring (Hamburg), and Dr. J. Jacob (Paris) discussed the testing of analgesic drugs on animals. The final session, in which Prof. C. A. Koele again took the chair, was devoted to practical applications to animals used in research. In the unavoidable absence of Prof. A. Haddow, Dr. E. J. Delorme described several arrangements devised at the Chester Beatty Research Institute for the comfort of the animals used. Major C. W. Hume (UFAW, London) directed attention to the desirability of ensuring that experimentation on animals be restricted to scientifically qualified persons who recognize their responsibility towards the rodents and other animals used, the training of technicians and of beginners in research being particularly important in this respect. A discussion on legislation for the protection of laboratory animals followed.

A report comprising the full text of the papers with summaries of the ensuing discussions is to be published by UFAW and will, it is hoped, be available early in 1962 .

\section{SOCIAL STUDIES IN BRITAIN}

$I^{\mathrm{N}}$ the debate on science in the House of Commons on July 10, Mrs. Judith Hart urged the need for a social sciences research council, referring particularly to the contribution which social science could make in dealing with the special problems of the new towns, in urban research and development generally, in the National Health Service, and in the economic and social problems arising out of automation and industrial change in general. Mr. D. Freeth, Parliamentary Secretary for Science, did not deal with this subject in his reply in that debate, but it was raised afterwards by Mr. A. Albu in a debate on August 4. In the meantime, on July 18, Mr. Freeth had stated in answer to a specific question from Mrs. Hart that the Council for Scientific and Industrial Research is reviewing the support given by the Department in this field, and considering whether there is need to alter the present organization for encouraging and supporting these studies. Mr. Freeth said that the Minister for Science expects to receive the Council's views in the autumn, and on August 4 he added that the House would expect the Minister to await the Council's advice, though he was authorized to emphasize the Minister's great interest in the social sciences. The Minister would note very carefully the views expressed in the debate; Lord Hailsham believed that more work should be done in the universities and elsewhere in this field, and his continuing study would be directed to strengthening the social sciences in future.

The debate on August 4 was notable for the very full review of the whole position of the research effort in Britain in this field at present, and warm appreciation of Mr. Freeth's statement was expressed by Mr. F. Peart. Mr. Freeth began by referring to the report of the Clapham Committee in 1946, as a result of which the University Grants Committee made earmarked grants from 1947 until 1952 for the social sciences at a steadily increasing rate. A change in policy led to the discontinuance of earmarked grants after 1957, but at the present time the Department of Scientific and Industrial Research is making grants

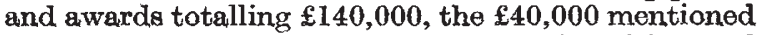
by Mr. Albu covering grants to universities and colleges of advanced technology only. For this purpose, the Department has a special committee, and in addition the Industrial Grants Committee of the Department has made a 5-year grant to the National Institute of Industrial Psychology, depending on the amount of money raised for the purpose by the Institute. A list of investigations supported by the Human Sciences Committee of the Department is available, and although all these awards are related to industry they cover a wide field. Mr. Freeth cited as examples research at the Birmingham College of Advanced Technology into social factors affecting relations and individual performance in factories; at the University of Durham into worker-management relations in four industries in the north-east of England of differing techniques; at Brunel College, into the subjective nature of judgments made in the inspection and quality control of manufactured goods; at the University of Leicester into problems of the employment of married women in hosiery factories; and at the University of Oxford into plantoperating skills in relation to automation.

In this context Mr. Freeth referred to the dissemination of the results of such research; for example, the Ergonomics Conference held in September 1960 and the series of meetings organized to introduce the topics discussed to the research associations.

About $f 60,000$ a year is being expended on research in this field at the Department's own laboratories, including, for example, the work at the Warren Springs Laboratory on ergonomics, such as the design and study of key-boards and a study in conjunction with the University of Manchester of secondary modern school-leavers. At the Building Research Station investigations are being made of the design and provision of flats for old people and the design of offices and hospitals. The Road Research Laboratory is continually examining the personal characteristics of road-users in relation to their behaviour on the road, and the National-Physical Laboratory is investigating motor-vehicle noise, the effects of the light in a room on colour rendering, and readers for blind people, and the British Iron and Steel Research Association and the British Boot and Shoe and Allied Trades Research Association have human science and ergonomic sections.

The Medical Research Council is spending some $£ 250,000$ in this field, at its own research units and 